\title{
MODEL PENGUKURAN TINGKAT KEPERCAYAAN PELANGGAN (ONLINE TRUST) TERHADAP SITUS E-COMMERCE (Studi Kasus pada Pelanggan E-Commerce di Provinsi Bali)
}

\author{
I Made Endra Wiartika Putra' ${ }^{1}$, , Gede Rasben Dantes², I Made Candiasa ${ }^{3}$ \\ 1 Universitas Pendidikan Ganesha \\ 2 Universitas Pendidikan Ganesha \\ ${ }^{3}$ Universitas Pendidikan Ganesha
}

\begin{abstract}
Abstrak
Penelitian ini bertujuan untuk mengetahui model pengukuran tingkat kepercayaan pelanggan terhadap situs e-commerce. Langkah awal yang dilakukan yaitu identifikasi faktor-faktor yang mempengaruhi kepercayaan pelanggan melalui studi literatur dan studi empirik untuk menentukan model analisis terhadap kepuasan pelanggan. Faktor yang mempengaruhi kepercayaan pelanggan untuk bertransaksi secara online yaitu pengetahuan konsumen terhadap e-commerce, reputasi penjual, resiko dalam transaksi, kemudahan penggunaan e-commerce, jaminan sistem, sikap/perilaku terhadap sistem dan sistem keamanan. Populasi dalam penelitian ini adalah masyarakat Provinsi Bali menggunakan metode purposive sampling dan snowball sampling dengan kriteria responden pernah berkunjung dan melakukan transaksi di e-commerce yang ada di Indonesia lebih dari 3 kali. Instrumen penelitian berupa kuesioner dengan data interval berskala 5 Likert. Instrumen terlebih dahulu diuji validitas isi dengan metode Robert Gregory, validitas empiris menggunakan rumus product moment, reliabilitas instrument menggunakan Cronbach's Alpha, dan menghasilkan 59 pernyataan yang dapat digunakan untuk pengambilan data. Jumlah responden yang digunakan dalam penelitian ini adalah sebanyak 126 responden. Teknik analisis data, pengujian hipotesis dan pengujian model menggunakan metode Structural Equation Modeling dengan bantuan aplikasi SPSS AMOS 21. Hasil penelitian ini melalui pengujian hipotesis menunjukkan bahwa pengetahuan tentang situs e-commerce dan perlindungan keamanan berpengaruh negatif dan tidak signifikan terhadap kepercayaan pelanggan. Resiko, kemudahan $e$ commerce, jaminan sistem dan sistem keamanan bukan menjadi sesuatu yang penting untuk dipertimbangkan dalam meningkatkan kepercayaan pelanggan karena pengaruhnya tidak signifikan. Reputasi yang dirasakan dan sikap merupakan hal yang perlu diperhatikan dan paling berpengaruh terhadap kepercayaan pelanggan pelanggan. Hasil penelitian ini kemudian diuji menggunakan goodness of fit index dan menghasilkan bahwa model penelitian tersebut dapat diterima dan dapat digunakan untuk meningkatkan keinginan pelanggan untuk bertransaksi online.
\end{abstract}

\begin{tabular}{lr} 
Keywords: & \\
\hline e-commerce, & $\begin{array}{r}\text { jaminan } \\
\text { sistem, }\end{array}$ \\
pelanguasan, & kemudahan \\
e-commerce, & \\
pengetahuan terhadap e- & commerce, reputasi, \\
resiko, sikap dan sistem \\
keamanan
\end{tabular}

\section{PENDAHULUAN}

Perkembangan pesat internet di Indonesia menjadikan Indonesia menjadi lahan bisnis online yang menjanjikan. Salah satu fenomena e-commerce saat ini yang mulai berkembang dengan pesat di Indonesia adalah dengan munculnya situs jual beli online. Banyak kemudahan yang didapatkan dalam transaksi secara online, akan tetapi masyarakat Indonesia mayoritas masih lebih suka untuk berbelanja secara konvensional, yang masih menjadi pertimbangan konsumen yaitu tingkat kepercayaan yang mereka tunjukan pada situs jual-beli tersebut.

Banyak konsumen yang masih mempertanyakan tentang sistem keamanan, kontrol terhadap informasi pribadi, integritas, kualitas barang, metode pembayaran dan kemampuan situs sendiri dalam mengelola jual beli online. Dengan adanya risiko belanja online ini dapat mengurangi kepercayaan konsumen untuk berbelanja online. Penelitian ini bertujuan untuk mempelajari pengaruh kepercayaan terhadap e-commerce (online trust) terhadap niat pembelian produk (online purchase intention) dan juga faktor yang mempengaruhi kepercayaan terhadap jasa jual beli online.

\footnotetext{
* Corresponding author.

E-mail Addresses: made.endra@yahoo.com (,I Made Endra Wiartika Putra $)$,
} 
Berdasarkan paparan tersebut di atas, faktor-faktor yang mempengaruhi kepercayaan pelanggan untuk bertransaksi secara online yaitu pengetahuan konsumen terhadap e-commerce (ecommerce knowledge), reputasi penjual (perceived reputation), resiko dalam transaksi (perceived risk), kemudahan penggunaan e-commerce (perceived ease of use), jaminan sistem (system assurance) sikap/perilaku terhadap sistem (attitude) dan sistem keamanan (security protection).

\section{METODE PENELITIAN}

Penelitian ini menggunakan pendekatan kuantitatif. Penelitian kuantitatif adalah penelitian yang tidak terlalu menitikberatkan kedalaman data, yang penting dapat merekam data sebanyak - banyaknya dari populasi yang luas dan pemecahan masalahnya didominassi oleh peran statistik. Berikut digambarkan model konseptual yang akan digunakan

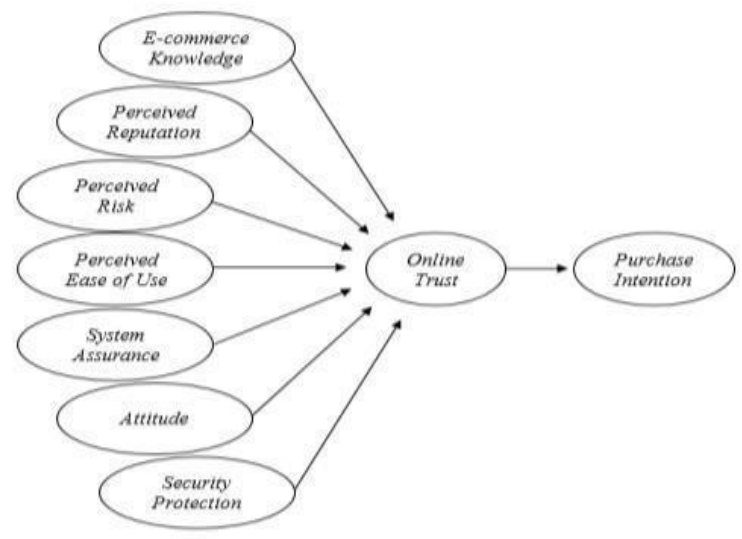

Populasi dalam penelitian ini adalah masyarakat Provinsi Bali yang berjumlah sebanyak 4.125.800 jiwa penduduk pada tahun 2016. Metode pengambilan sampel dilakukan dengan metode Purposive sampling (judgmental) dan snowball sampling. Kriteria utama pemilihan sampel di dalam penelitian ini adalah masyarakat Provinsi Bali yang pernah berkunjung dan melakukan transaksi di e-commerce yang ada di Indonesia lebih dari 3 kali.

Variabel pada penelitian ini terdiri dari dua jenis variabel, yaitu variabel independen dan variabel dependen. Variabel bebas dalam penelitian ini adalah terdiri dari e-commerce knowledge (X1), perceived reputation (X2), perceived risk (X3) dan perceived ease of use (X4), system assurance (X5), attitude (X6) dan Security Protection (X7). Sedangkan variabel terikat dalam penelitian ini adalah online trust (Y1) dan purchase intention (Y2).

Penelitian ini menggunakan pendekatan kuantitatif, maka dari itu data yang dihasilkan dalam bentuk angka atau bilangan yang dapat diolah atau dianalisa dengan menggunakan tehnik perhitungan matematika atau statistika. Pengumpulan data dalam penelitian ini menggunakan teknik dokumentasi untuk menjaring data jumlah populasi penelitian, dan dengan angket atau kuesioner digunakan untuk menjaring data $\mathrm{X}_{1}, \mathrm{X}_{2}, \mathrm{X}_{3}, \mathrm{X} 4$, Y1 dan Y2 yang diperoleh dari populasi masyarakat Provinsi Bali. Format kuesioner disusun dengan menggunakan skala Likert, yaitu skala yang membuat responden untuk menentukan tingkat setuju dan ketidaksetujuan dari setiap pernyataan yang ada di dalam kuesioner, dengan pilihan Sangat Tidak Setuju, Tidak Setuju, Kurang Setuju, Setuju dan Sangat Setuju.

Untuk melihat kecendrungan variabel e-commerce knowledge, perceived reputation, perceived risk, perceived ease of use, system assurance, attitude, online trust, security protection dan online purchase intention rata-rata skor ideal dari semua objek penelitian dibandingkan dengan rata-rata kenyataan. Dari rerata dikelompokkan kecenderungannya menjadi lima kategori dengan norma kerangka teoritik kurva normal ideal.

Persyaratan yang berkaitan dengan teknik analisis data harus dibuktikan secara statistik. Adapun uji persyaratan analisisnya adalah sebagai berikut. Uji normalitas sebaran data untuk mengetahui apakah sebaran frekuensi skor pada setiap variabel berdistribusi normal atau tidak. Uji linieritas dan keberartian koefisien regresi untuk mengetahui bentuk hubungan antara variabel terkait dengan masing-masing variabel bebas. Uji multikolinieritas untuk mengetahui antara sesama variabel bebas tidak terdapat muatan factor bersama yang terlalu tinggi. Uji heterokedastisitas untuk menguji apakah dalam sebuah model regresi terjadi ketidaksamaan varian dari residual satu pengamatan ke pengamatan 
yang lain. Uji autokorelasi untuk menegetahui nilai variabel masa lalu memiliki pengaruh terhadap nilai variabel masa kini.

Analisis dan pengolahan data menggunakan alat analisis Structural Equation Modelling (SEM) dari paket software SPSS AMOS 21 dalam model dan pengujian hipotesis. Teknik ini dilakukan untuk menjelaskan secara menyeluruh hubungan antar variabel yang ada dalam penelitian.

\section{ANALISIS DAN PEMBAHASAN}

Kuesioner yang terkumpul adalah sebanyak 149, setelah hasil seleksi jumlah responden yang digunakan dalam penelitian ini adalah sebanyak 126 responden. Profil responden ini terdiri dari jenis kelamin, usia, pendidikan terakhir, pekerjaan, lokasi tempat tinggal, rata-rata lama penggunaan internet per hari, device yang sering digunakan internetan, lama pengalaman dalam menggunakan situs $e$ commerce, situs e-commerce yang pernah digunakan dan berapa kali responden pernah bertransaksi di situs e-commerce.

\begin{tabular}{|c|c|c|}
\hline Jenis Kelamin & Frekuensi & Persentase \\
\hline 1. Laki-laki & 68 & 53,97 \\
\hline 2. Perempun & 58 & 46,03 \\
\hline Usia & Frekuensi & Persentase \\
\hline$<18$ tahun & 7 & 5,58 \\
\hline $18-21$ tahun & 27 & 21,43 \\
\hline $22-28$ tahun & 73 & 57,94 \\
\hline $29-35$ tahun & 16 & 12,70 \\
\hline$>35$ tahun & 3 & 2,38 \\
\hline Pendidikan Terakhir & Frekuensi & Persentase \\
\hline SMA/SMK & 36 & 28,57 \\
\hline DIPLOMA & 13 & 10,32 \\
\hline S1 & 73 & 57,94 \\
\hline $\mathrm{S} 2$ & 4 & 3,17 \\
\hline Pekerjaan & Frekuensi & Persentase \\
\hline Pelajar & 23 & 18,25 \\
\hline Guru & 23 & 18,25 \\
\hline Pegawai Negeri & 20 & 15,87 \\
\hline Pegawai Swasta & 33 & 26,19 \\
\hline Wiraswasta & 25 & 19,84 \\
\hline IRT & 2 & 1,59 \\
\hline Lokasi Tinggal & Frekuensi & Persentase \\
\hline Denpasar & 36 & 28,57 \\
\hline Badung & 22 & 17,46 \\
\hline Gianyar & 8 & 6,35 \\
\hline Bangli & 1 & 0,79 \\
\hline Klungkung & 2 & 1,59 \\
\hline Karangasem & 2 & 1,59 \\
\hline Tabanan & 12 & 9,52 \\
\hline Jembrana & 34 & 26,98 \\
\hline Buleleng & 9 & 7.14 \\
\hline Penggunaan Internet & Frekuensi & Persentase \\
\hline$<1$ jam & 6 & 4,76 \\
\hline $1-5 \mathrm{jam}$ & 57 & 45,24 \\
\hline $6-10$ jam & 44 & 34,92 \\
\hline$>10 \mathrm{jam}$ & 19 & 15,08 \\
\hline Device & Frekuensi & Persentase \\
\hline Mobile & 105 & 83,33 \\
\hline Komputer & 21 & 16,67 \\
\hline $\begin{array}{l}\text { Pengalaman } \\
\end{array}$ & Frekuensi & Persentase \\
\hline$<1$ tahun & 34 & 26,98 \\
\hline
\end{tabular}




\begin{tabular}{|c|c|c|}
\hline $1-2$ tahun & 47 & 37,30 \\
\hline$>2$ tahun & 45 & 35,72 \\
\hline Situs E-commerce & Frekuensi & \\
\hline Bukalapak & 59 & \\
\hline OLX & 66 & \\
\hline Tokopedia & 62 & \\
\hline Bli bli & 13 & \\
\hline Zalora & 18 & \\
\hline Shopee & 21 & \\
\hline Bhineka & 12 & \\
\hline Kaskus & 17 & \\
\hline Lazada & 24 & \\
\hline Bertransaksi & Frekuensi & Persentase \\
\hline $3-6$ kali & 63 & 50,00 \\
\hline 7 - 10 kali & 17 & 13,49 \\
\hline > 10 kali & 46 & 36,51 \\
\hline
\end{tabular}

Penentu kecenderungan kategori dari variabel didasarkan pada kategori norma kerangka teoritik kurva normal ideal, hasilnya sebagai berikut.

\begin{tabular}{clc}
\hline No & \multicolumn{1}{c}{ Variabel } & Kategori \\
\hline 1 & E-commerce Knowledge & Baik \\
2 & Perceived Reputation & Cukup Baik \\
3 & Perceived Risk & Cukup Baik \\
4 & Perceived Ease of Use & Baik \\
5 & System Assurance & Cukup Baik \\
6 & Attitude & Baik \\
7 & Security Protection & Cukup Baik \\
8 & Online Trust & Cukup Baik \\
9 & Online Purchase Intention & Cukup Baik \\
\hline
\end{tabular}

Uji Prasyarat Analisis

Uji Normalitas Sebaran Data

Uji normalitas bertujuan untuk mengetahui variabel-variabel independen dan dependen harus berdistribusi normal atau mendekati normal yaitu jika signifikan lebih besar dari 0,05 [5].

\begin{tabular}{clc}
\hline No & \multicolumn{1}{c}{ Variabel } & Nilai \\
\hline 1 & E-commerce Knowledge & 0,2 \\
2 & Perceived Reputation & 0,2 \\
3 & Perceived Risk & 0,2 \\
4 & Perceived Ease of Use & 0,2 \\
5 & System Assurance & 0,19 \\
6 & Attitude & 0,2 \\
\hline
\end{tabular}




\begin{tabular}{lll}
7 & Security Protection & 0,7 \\
8 & Online Trust & 0,2 \\
\hline
\end{tabular}

\section{Uji Linieritas dan Keberartian Koefisien Regresi}

Pedoman untuk melihat linieritas variabel adalah dengan mengkaji lajur Dev. from linierity dari modul means, sedangkan untuk melihat keberartian arah regresinya berpedoman pada lajur linierity.

\begin{tabular}{lll}
\hline Variabel & Linieritas & Koefisien \\
\hline $\mathrm{X} 1{ }^{\natural} \mathrm{Y} 1$ & Linier & Signifikan \\
$\mathrm{X} 2{ }^{\natural} \mathrm{Y} 1$ & Linier & Signifikan \\
$\mathrm{X} 3{ }^{\natural} \mathrm{Y} 1$ & Linier & Signifikan \\
$\mathrm{X} 4{ }^{\natural} \mathrm{Y} 1$ & Linier & Signifikan \\
$\mathrm{X} 5{ }^{\natural} \mathrm{Y} 1$ & Linier & Signifikan \\
$\mathrm{X} 6{ }^{\natural} \mathrm{Y} 1$ & Linier & Signifikan \\
$\mathrm{X} 7{ }^{\natural} \mathrm{Y} 1$ & Linier & Signifikan \\
$\mathrm{Y} 1{ }^{\square} \mathrm{Y} 2$ & Linier & Signifikan \\
\hline
\end{tabular}

\section{Uji Multikolinieritas}

Alat statistik yang digunakan untuk menguji gangguan multikolinieritas adalah nilai tolerance dan variance inflation factor (VIF).

\begin{tabular}{lccl}
\hline Variabel & Tolerance & VIF & Kesimpulan \\
X1 & 0,555 & 1,802 & Tidak terjadi \\
X2 & 0,359 & 2,788 & Tidak terjadi \\
X3 & 0,541 & 1,847 & Tidak terjadi \\
X4 & 0,423 & 2,366 & Tidak terjadi \\
X5 & 0,431 & 2,319 & Tidak terjadi \\
X6 & 0,324 & 3,090 & Tidak terjadi \\
X7 & 0,798 & 1,254 & Tidak terjadi \\
Y1 & 1,000 & 1,000 & Tidak terjadi \\
\hline
\end{tabular}

\section{Uji Heteroskedastisitas}

Untuk melihat ada tidaknya heteroskedastisitas adalah menggunakan uji Glejser, dengan cara melakukan regresi variabel independen dengan nilai absolut dari residualnya.

\begin{tabular}{lcc}
\hline Variabel & Signifikansi & Kesimpulan \\
\hline $\mathrm{X} 1$ & 0,773 & Tidak terjadi
\end{tabular}




\begin{tabular}{lrr}
\hline X2 & 0,100 & Tidak terjadi \\
X3 & 0,259 & Tidak terjadi \\
X4 & 0,274 & Tidak terjadi \\
X5 & 0,711 & Tidak terjadi \\
X6 & 0,247 & Tidak terjadi \\
X7 & 0,404 & Tidak terjadi \\
X8 & 0,204 & Tidak terjadi \\
\hline
\end{tabular}

\section{Uji Autokorelasi}

Menggunakan uji run test, untuk melihat apakah data residual bersifat acak atau tidak. Hasil uji run test lebih besar daripada 0,05. Dengan demikian, dapat disimpulkan bahwa data yang dipergunakan cukup random sehingga tidak terdapat masalah autokorelasi pada data yang diuji.

\section{Uji Hipotesis Penelitian}

\section{Penyusunan Diagram Alur}

Diagram alur hubungan kausalitas antar konstruk beserta indikatornya sebagai berikut

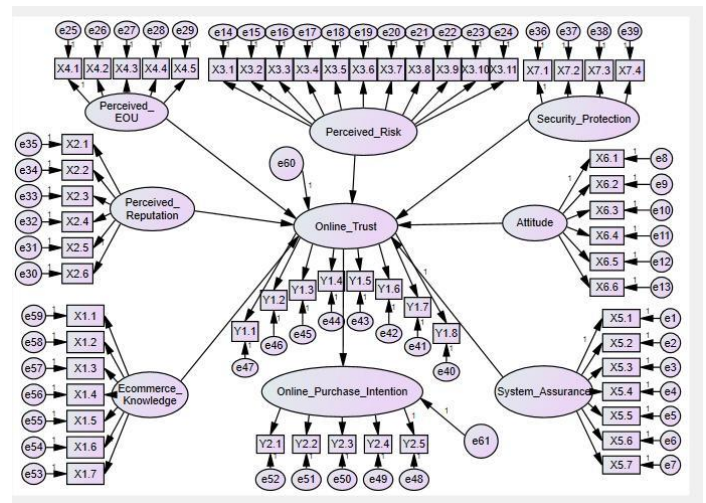

Indikator yang memiliki loading factor kurang dari 0,50 dikeluarkan dari model (Ghozali). Setelah itu dilakukan re-estimasi, hasil model struktural yang dihasilkan sebagai berikut

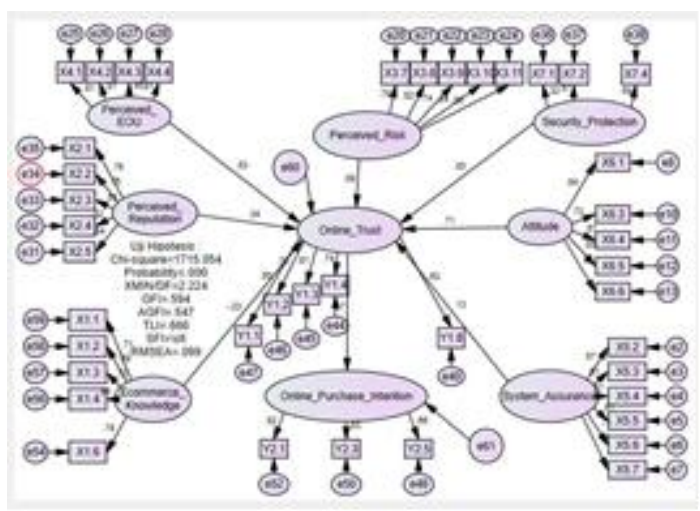

Karena nilai loading factor sudah diatas 0,50 dan construct reliability diatas 0,60 maka semua konstruk dalam penelitian ini layak untuk digunakan dalam model penelitian.

\section{Analisis Data}


Hasil perhitungan menggunakan metode SEM sebagaimana berikut.

\begin{tabular}{|c|c|c|c|c|c|}
\hline & $\begin{array}{r}\text { Estima } \\
\text { te }\end{array}$ & $\begin{array}{l}\text { Standardi } \\
\text { zed } \\
\text { Estimates }\end{array}$ & S.E. & C.R. & $\mathbf{P}$ \\
\hline $\mathrm{X} 1^{12} \mathrm{Y} 1$ & 231 & 0,337 & ,055 & 4,181 & $* * *$ \\
\hline $\mathrm{X} 2^{2} \mathrm{Y} 1$ & ,020 & 0,027 & ,051 & ,402 & 688 \\
\hline X3 $3^{2} 1$ & ,046 & 0,087 & ,038 & 1,202 & ,229 \\
\hline $\mathrm{X} 4{ }^{2} \mathrm{Y} 1$ &,- 006 & $-0,003$ & 149 &,- 039 & 969 \\
\hline$X 5^{0} \mathrm{Y} 1$ & ,455 & 0,709 & 071 & 6,391 & *** \\
\hline X6? Y1 & 102 & 0,125 & ,061 & 1,666 & ,096 \\
\hline X7? Y1 &,- 183 & $-0,231$ & ,061 & $-3,010$ & ,003 \\
\hline Y10 Y2 &, 564 & 0,569 & ,132 & 4,287 & *** \\
\hline
\end{tabular}

Pengujian terhadap hipotesis yang diajukan dalam penelitian ini hasilnya dikemukakan sebagai berikut

\section{C.R.}

\begin{tabular}{|c|c|c|c|c|}
\hline Hipotesis & Var1 & Var2 & (P-value) & Ket. \\
\hline H1 & $\mathrm{X} 1$ & Y1 & $\begin{array}{l}-3,010 \\
(0,003)\end{array}$ & Ditolak \\
\hline $\mathrm{H} 2$ & $\mathrm{X} 2$ & Y1 & $\begin{array}{c}4,181 \\
(0,000)\end{array}$ & Diterima \\
\hline H3 & X3 & Y1 & $\begin{array}{c}1,202 \\
(0,229)\end{array}$ & Diterima \\
\hline $\mathrm{H} 4$ & $\mathrm{X} 4$ & Y1 & $\begin{array}{c}0,402 \\
(0,688)\end{array}$ & Diterima \\
\hline H5 & X5 & Y1 & $\begin{array}{c}1,666 \\
(0,096)\end{array}$ & Diterima \\
\hline H6 & X6 & Y1 & $\begin{array}{c}6,391 \\
(0,000)\end{array}$ & Diterima \\
\hline $\mathrm{H} 7$ & X7 & Y1 & $\begin{array}{l}-0,039 \\
(0,096)\end{array}$ & Ditolak \\
\hline H8 & Y1 & Y2 & $\begin{array}{r}4,287 \\
(0,000) \\
\end{array}$ & Diterima \\
\hline
\end{tabular}

Pada taraf keyakinan 0,05, variabel disebut berpengaruh signifikan apabila nilai C.R (Critical Ratio) $>1,96$ dan P-value $<0.05$, maka kesimpulannya adalah.

a) Pengetahuan tentang situs e-commerce (E-commerce knowledge) pelanggan berpengaruh secara negatif dan tidak signifikan terhadap kepercayaan (Online Trust) pelanggan.

b) Reputasi yang dirasakan (Perceived Reputation)

pelanggan tentang situs e-commerce berpengaruh positif dan signifikan terhadap kepercayaan (Online Trust) pelanggan. 
c) Resiko yang dirasakan (Perceived Risk)

pelanggan dalam melakukan transaksi berpengaruh positif walaupun tidak signifikan terhadap kepercayaan (Online Trust) pelanggan.

d) Kemudahan yang dirasakan (Perceived Ease of Use) pelanggan dalam penggunaan sistem $e$ commerce berpengaruh positif walaupun tidak signifikan terhadap kepercayaan (Online Trust) pelanggan.

e) Kenyamanan (System Assurance) pelanggan dalam bertansaksi di e-commerce berpengaruh positif walaupun tidak signifikan terhadap kepercayaan (Online Trust) pelanggan.

f) Sikap (Attitude) penjual terhadap pelanggan dalam bertransaksi di e-commerce berpengaruh positif dan signifikan terhadap kepercayaan (Online Trust) pelanggan.

g) Perlindungan keamanan (Security Protection) yang diberikan selama melakukan transaksi berpengaruh negatif dan tidak signifikan terhadap kepercayaan (Online Trust) pelanggan.

h) Kepercayaan (Online Trust) pelanggan terhadap e-commerce berpengaruh positif dan signifikan

terhadap keinginan pelanggan untuk bertransaksi online (Online Purchase Intention) mengguanakan $e$-commerce.

\section{Pengujian Model.}

Kriteria untuk menerima suatu model (data fit) dapat dilakukan dengan mengukur goodness of fit index model penelitian yang dihasilkan. Goodness of fit index merupakan cara untuk menguji kelayakan model yang tujuannya untuk mengevaluasi secara umum derajat kecocokan atau goodness of fit antara data dengan model.

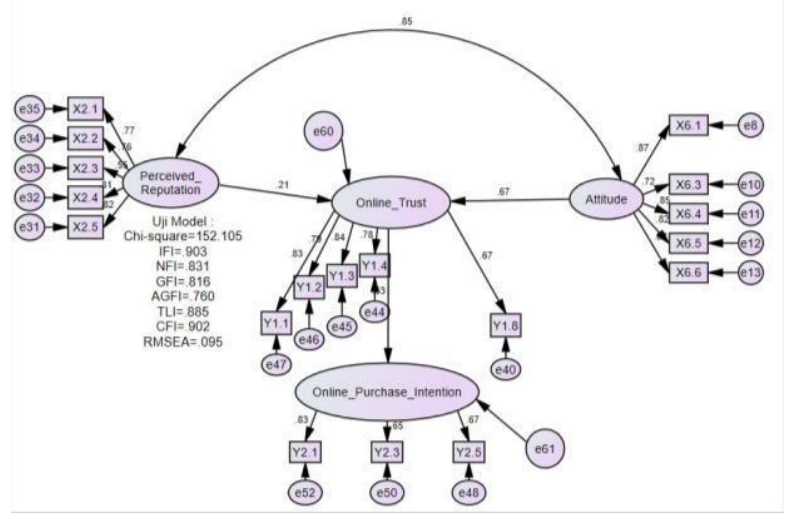

Hasil pengujian goodness of fit index model penelitian dapat dilihat pada tabel berikut.

\begin{tabular}{ccc}
\hline Goodness & Hasil & \\
& & Evaluasi Model \\
of Fit Index & Analisis & \\
Chi Square & 152,105 & Baik \\
\hline
\end{tabular}




\begin{tabular}{ccc}
\hline GFI & 0,816 & Marginal / Mendekati \\
AGFI & 0,760 & Kurang \\
IFI & 0,903 & Baik \\
NFI & 0,831 & Marginal / Mendekati \\
TLI & 0,885 & Marginal / Mendekati \\
CFI & 0,902 & Baik \\
RMSEA & 0,95 & Marginal / Mendekati \\
\hline
\end{tabular}

Dengan demikian maka model penelitian tersebut dapat diterima dan dapat digunakan untuk meningkatkan kepercayaan pelanggan dalam menumbuhkan keinginan pelanggan untuk bertransaksi online (online purchase intention).

\section{KESIMPULAN}

Berdasarkan hasil penelitian yang dilakukan, dapat disimpulkan sebagai berikut : a) Variabel $e$ commerce knowledge dan security protection berpengaruh negatif dan tidak signifikan terhadap kepercayaan (online trust) pelanggan menggunakan situs e-commerce, sehingga variable tersebut tidak menjadi sesuatu pertimbangan bagi pengguna e-commerce di Bali untuk bertransaksi di situs e-commerce, b) variabel perceived risk, perceived ease of use, system assurance dan security protection berpengaruh positif terhadap kepercayaan (online trust) pelanggan menggunakan situs e-commerce namun pengaruh tidak signifikan terhadap online trust, sehingga bukan menjadi sesuatu yang penting untuk dipertimbangkan dalam meningkatkan kepercayaan pelanggan terhadap situs e-commerce, c) Variabel perceived reputation dan attitude penjual terhadap pelanggan dalam bertransaksi di e-commerce menghasilkan pengaruh yang positif dan sangat signifikan terhadap kepercayaan pelanggan (online trust). Selain itu variabel online trust pelanggan terhadap e-commerce berpengaruh positif dan sangat signifikan terhadap online purchase intention menggunakan e-commerce. Sehingga dapat disimpulkan reputasi yang dimiliki situs e-commerce, sikap penjual terhadap pelanggan, dan kepercayaan pelanggan mempengaruhi niat pembelian pelanggan melalui situs e-commerce, d) Hasil pengujian model pengukuran tingkat kepercayaan pelanggan (online trust) terhadap situs e-commerce menggunakan goodness of fit index menghasilkan bahwa secara keseluruhan pengujian model memperoleh hasil baik, dengan demikian maka model penelitian tersebut dapat diterima.

Berdasarkan hasil penelitian, pembahasan dan kesimpulan yang diperoleh, dapat disarankan beberapa hal sebagai berikut. a) Bagi penyedia jasa situs e-commerce supaya memperhatikan dan memperbaiki pelayanan di bagian reputasi situs di mata pelanggannya dan sikap yang diberikan oleh penyedia jasa kepada pelanggannya karena variable tersebut sangat berpengaruh dan memberikan pengaruh yang sangat signifikan terhadap kepercayaan pelanggan, b) Bagi peneliti selanjutnya, untuk menambah jumlah sampel penelitin, melakukan pengujian bagaimana perilaku konsumen setelah melakukan transaksi melalui situs e-commerce. Menambah variable penelitian yang mempengaruhi niat, c) pembelian online (online purchase intention) di situs e-commerce dengan melibatkan variabel selain online trust. Perlu dilakukan penelitian untuk melihat perilaku konsumen dalam pembelian produk melalui situs jual beli online.

\section{DAFTAR PUSTAKA}

Morgan dan Hunt. 2006. "The Commitment-Trust Theory of Relationship Marketing”. Journal of Marketing.

Ba dan Pavlou. 2002. "Evidence of the effect of trust building technology in electronic markets: price premiums and buyer behavior". Society for Information Management and The Management Information Systems Research Center Minneapolis, MN, USA.

Li, Rong et.al. 2007. "The Effects Of Internet Shoppers' Trust On Their Purchasing Intention In China. JISTEM J.Inf.Syst.Technol.Management (Online)"

Jarvenpaa \& Tractinsky, 1999. “Consumer Trust in an Internet Store: A Cross-Cultural Validation". Journal of Computer-Mediated Communication. 
Fika, Ainun. 2015. "Pengaruh Keamanan, Kemudahan, dan Risiko Kinerja terhadap Keputusan Pembelian secara Online si Tokopedia.com.

Suhir, Imam Suyadi, dan Riyadi. Moch. 2014. "Pengaruh Persepsi Risiko, Kemudahan, dan Manfaat Terhadap Keputusan Pembelian Secara Online”. Malang: Universitas Brawijaya.

Corbit, B. J., Thanasankit, T., dan Yi, H. 2003. "Trust and E-commerce: a Study of ConsumerPerceptions,Electronic Commerce Research and Application".

Yamin, S dan Kurniawan, H, 2009. "Structural Equation Modeling Belajar Lebih Mudah Teknik Analisis Data Kuesioner dengan Lisrel-PLS”. Jakarta : Penerbit Salemba Infotek. 